\title{
Penerapan Multi Factor Evaluation Process Dalam Penerimaan Asisten Dosen Pada STMIK Triguna Dharma
}

\author{
Puji Sari Ramadhan \\ Program Studi Sistem Informasi, STMIK Triguna Dharma, Medan, Indonesia \\ Email: pujisariramadhan@gmail.com
}

\begin{abstract}
Abstrak
Dalam membantu peran seorang dosen dalam melaksanakan pembelajaran serta sebagai upaya dalam peningkatan kualitas pembelajaran maka perlu mengangkat Asisten Dosen yang juga bertugas dalam menggantikan peran dosen yang berhalangan hadir. Pada proses penerimaan Asisten Dosen perlu menggunakan kriteria dan penilaian yang objektif serta akurat dengan menggunakan metode perhitungan memiliki konsep universal dalam keilmuan Sistem Pendukung Keputusan. Untuk itu perlu membangun sebuah sistem penilaian yang nantinya dapat menghasilkan keputusan dalam penyeleksian calon Asisten Dosen. Berdasarkan pandangan tersebut maka dalam penerimaan Asisten Dosen akan menggunakan salah satu metode dalam Sistem Pendukung Keputusan yang memiliki kemampuan dalam menghasilkan sebuah keputusan berdasarkan rangking atau peringkat dari masing-masing alternatif yaitu metode Multi Factor Evaluation Process. Dengan adanya penerapan metode ini yang akan diterapkan dalam sebuah sistem aplikasi dapat membantu pihak institusi dalam menentukan kelayakan dari proses penerimaan Asisten Dosen sehingga nantinya akan terpilih Asisten Dosen berdasarkan perangkingan nilai yang telah dihasilkan melalui proses perhitungan metode Multi Factor Evaluation Process.
\end{abstract}

Kata Kunci: Sistem Pendukung Keputusan, Multi Factor Evaluation Process, Asisten Dosen, Peringkat.

\section{Abstract}

In helping the role of a lecturer in carrying out learning as well as an effort in improving the quality of learning it is necessary to appoint a Lecturer Assistant who is also in charge of replacing the role of the lecturer who is unable to attend. In the acceptance process of the Lecturer Assistant, it is necessary to use objective and accurate criteria and assessment using the calculation method to have a universal concept in the science of Decision Support Systems. For this reason, it is necessary to build a scoring system that can later produce decisions in selecting prospective Lecturer Assistants. Based on these views, the acceptance of the Lecturer Assistant will use one method in the Decision Support System that can produce a decision based on the ranking or ranking of each alternative, namely the Multi-Factor Evaluation Process method. With the application of this method that will be applied in an application, the system can help the institution in determining the feasibility of the acceptance process of the Lecturer Assistant so that later the Lecturer Assistant will be chosen based on the ranking of values that have been generated through the Multi-Factor Evaluation Process.

Keywords: Decision Support System, Multi Factor Evaluation Process, Assistant Lecturer, Ranking.

\section{PENDAHULUAN}

Asisten Dosen merupakan seorang staff kependidikan yang memilki tugas untuk membantu peran dosen dalam melaksanakan kegiatan pembelajaran serta menggantikan peran dosen dalam menyampaikan materi pembelajaran pada saat dosen berhalangan hadir. Dengan kehadiran Asisten Dosen ini dapat memberikan pengaruh besar bagi peningkatan kualitas pembelajaran institusi serta terselenggaranya kegiatan perkuliahan yang berjalan dengan baik. Tentunya dalam penerimaan Asisten Dosen perlu melakukan seleksi dan penilaian terhadap kriteria yang telah ditetapkan institusi sehingga nantinya akan menghasilkan keputusan Asisten Dosen yang layak sesuai dengan kebutuhan institusi.

Berdasarkan keadaan yang telah dikemukakan maka perlu membangun sebuah sistem yang mampu menghasilkan sebuah keputusan dari alternatif yang ada berdasarkan kriteria yang telah ditetapkan dengan menerapkan konsep keilmuan Sistem Pendukung Keputusan. Penggunaan konsep Sistem Pendukung Keputusan ini telah banyak digunakan dalam mencari dan menghasilkan keputusan dalam beberapa kasus, seperti dalam [1] digunakannya Sistem Pendukung Keputusan untuk pemilihan polisi di sektor belawan, kemudian pada [2] dijelaskan bahwa Sistem Pendukung Keputusan digunakan dalam penentuan kebijakan ekonomi digital, selanjutnya dalam[3] dikemukakan bahwa Sistem Pendukung Keputusan dipergunakan dalam proses manajemen informasi, selain itu[4] penerapan Sistem Pendukung Keputusan telah diuji untuk pemilihan laptop dan [5]alat elektronik. Kemudian dalam[6] diterapkan konsep Decision Support System dalam menentukan bantuan terhadap keluarga kurang mampu, selanjutnya pada[7] digunakan dalam pengelolaan akses kesehatan, selain itu [8] penentuan kredit perumahan juga menggunakan cabang ilmu Decision Support System yaitu MOORA.

Sistem Pendukung Keputusan ini nantinya akan menerapkan metode Multi Factor Evaluation Process dalam proses penyeleksian Asisten Dosen sehingga nantinya akan menghasilkan nilai dari seleksi dari calon Asisten Dosen yang kemudian akan dirunutkan berdasarkan rangking dari nilai tertinggi sampai terendah untuk diberikan kepada pimpinan untuk menyesuaikan dengan kuota yang ditetapkan. Penerapan Multi Factor Evaluation Process dimulai dengan pembentukan kriteria beserta nilai bobot kemudian dilanjutkan dengan melakukan penilaian terhadap alternatif yang nantinya akan dihitung dengan Multi Factor Evaluation Process sehingga pada akhirnya akan dihasilkan nilai dari setiap masing-masing alternatif yang telah dihitung. 
Dengan adanya Sistem Pendukung Keputusan ini nantinya dapat digunakan oleh institusi dalam menentukan pemilihan Asisten Dosen melalui proses perhitungan Multi Factor Evaluation Process sehingga dapat dijadikan sebagai bagian dari pendukung dalam pengambilan keputusan.

\section{METODE PENELITIAN}

\subsection{Sistem Pendukung Keputusan}

Sistem merupakan satu kesatuan elemen yang saling berhubungan antara satu dengan yang lainnya[9], sementara itu Sistem Pendukung Keputusan adalah bagian dari sistem informasi yang diterapkan ke dalam komputer yang berfungsi sebagai alat untuk menghasilkan kesimpulan atau membuat keputusan berdasarkan kriteria yang disajikan[10].

\subsection{Multi Factor Evaluation Process}

Metode ini merupakan jenis dari Multi Criteria Decision Making yang tergolong dalam pengembangan DSS (Decision Support System). Dalam metode ini menerapkan skala prioritas dalam penentuan bobot kriteria berdasarkan tingkat ungggulan atau kepentingan[11]. Berikut fungsi persamaan dari Multi Criteria Decision Making:

$$
T B E=\sum_{\mathrm{n}}^{1}\left([\mathrm{NTK}=\mathrm{NBK} \times \mathrm{NEF}]+\ldots+[\mathrm{NTK}=\mathrm{NBK} \times \mathrm{NEF}]_{\mathrm{n}}\right)
$$

Keterangan :

TBE : Total Bobot Evaluasi

NTK : Nilai Total Kriteria

NBF : Nilai Bobot Kriteria

NEF : Nilai Evaluasi Faktor

\section{ANALISA DAN PEMBAHASAN}

Dalam melakukan penelitian ini diperlukan penggunaan metode penelitian Reserch and Development yang mempunyai kemampuan untuk menghasilkan sistem dalam bentuk suatu software aplikasi, nantinya yang akan diimplementasikan dalam melakukan proses penyeleksian terhadap pemilihan Asisten Dosen berdasarkan kriteria penilaian yang telah ditetapkan sehingga akan menghasilkan sebuah kesimpulan berupa keputusan dalam bentuk nilai perangkingan. Selain menggunakan metode penelitian, terdapat pula kerangka kerja yang digunakan dalam mendukung penenlitian ini diantaranya adalah pembentukan kriteria beserta nilai bobot, kemudian melakukan perhitungan dengan menggunakan metode Multi Factor Evaluation Process dan melakukan perangkinan nilai berdasarkan penilaian yang telah dilakukan serta pengimplementasian sistem dalam bentuk layanan aplikasi.

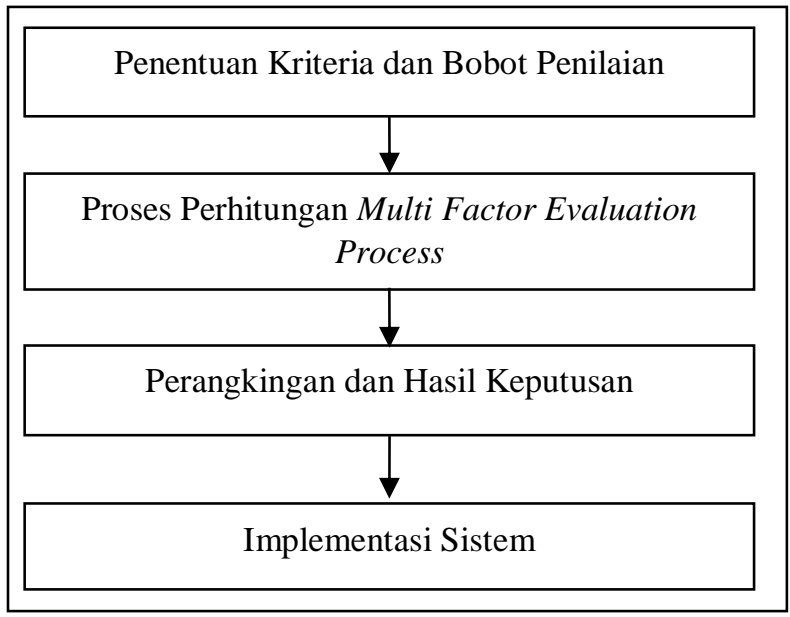

Gambar 1. Kerangka Kerja Penelitan

\subsection{Penentuan Kriteria Penilaian}

Dalam pembangunan Sistem Pendukung Keputusan dalam proses penerimaan Asisten Dosen dengan menggunakan Multi Factor Evaluation Process, dibutuhkan penetapan kriteria-kriteria penilaian yang menjadi acuan dalam proses perhitungan menggunakan Multi Factor Evaluation Process. Berikut ini merupakan kriteria penilaiaan dari proses penerimaan Asisten Dosen. 
Tabel 2. Data Kriteria

\begin{tabular}{cclc}
\hline No & Kode Kriteria & \multicolumn{1}{c}{ Daftar Kriteria } & Nilai Bobot \\
\hline 1 & K001 & Indeks Penilaian Kumulatif & $10 \%$ \\
\hline 2 & K002 & Tes Potensi Akademik & $15 \%$ \\
\hline 3 & K003 & Mikroteaching & $40 \%$ \\
\hline 4 & K004 & Wawancara & $20 \%$ \\
\hline 5 & K005 & Tes Psikotes & $15 \%$ \\
\hline
\end{tabular}

Dari data kriteria yang telah dipaparkan maka selanjutnya akan dilakukan proses penilaian terhadap masingmasing alternatif yaitu para calon Asisten Dosen sesuai dengan proses perhitungan metode Multi Factor Evaluation Process.

\subsection{Proses Perhitungan}

Pada tahapan ini akan dilakukan proses perhitungan dengan menggunakan Multi Factor Evaluation Process yang terlebih dahulu akan dilakukan proses penilaian dari masing-masing alternatif. Berikut merupakan hasil penilaian dari alternatif yang ada :

Tabel 3. Data Alternatif

\begin{tabular}{cclccccc}
\hline No & $\begin{array}{c}\text { Kode } \\
\text { Alternatif }\end{array}$ & Daftar Calon Asisten Dosen & K001 & K002 & K003 & K004 & K005 \\
\hline 1 & A001 & Masyuni Hutasuhut & 70 & 85 & 80 & 80 & 75 \\
\hline 2 & A002 & Nur Yanti Lumban Gaol & 80 & 75 & 75 & 85 & 80 \\
\hline 3 & A003 & Khairi Ibnu Utama & 70 & 85 & 85 & 75 & 80 \\
\hline 4 & A004 & Gilang Ramadhan & 80 & 90 & 70 & 75 & 75 \\
\hline 5 & A005 & Afdal Alhafiz & 80 & 75 & 80 & 80 & 85 \\
\hline 6 & A006 & Amrullah & 70 & 80 & 85 & 80 & 75 \\
\hline 7 & A007 & Wahyu Riansyah & 90 & 90 & 75 & 80 & 80 \\
\hline 8 & A008 & Muhammad Rendy & 80 & 75 & 90 & 70 & 85 \\
\hline 9 & A009 & Khuzaimah Panjaitan & 80 & 85 & 85 & 90 & 70 \\
\hline 10 & A010 & Deski Rilana & 70 & 80 & 75 & 80 & 80 \\
\hline
\end{tabular}

Setelah melakukan penilaian terhadap alternatif yang ada, maka selanjutnya dilakukan proses perhitungan dengan menggunakan fungsi persamaan dari metode Multi Factor Evaluation Process yang menyesuaikan dengan bobot kriteria yang sudah ditetapkan. Berikut proses dari penerapan metode Multi Factor Evaluation Process dalam pemilihan Asisten Dosen :

1. Penilaian terhadap alternatif A001 atas nama Masyuni Hutasut, berikut pemaparan dari proses perhitungan dari Multi Factor Evaluation Process :

Tabel 4. Data Penilaian Alternatif Pertama

\begin{tabular}{cclccc}
\hline No & $\begin{array}{c}\text { Kode } \\
\text { Kriteria }\end{array}$ & \multicolumn{1}{c}{ Daftar Kriteria } & Nilai Bobot & $\begin{array}{c}\text { Nilai } \\
\text { Alternatif }\end{array}$ & $\begin{array}{c}\text { Hasil } \\
\text { Perhitungan }\end{array}$ \\
\hline 1 & K001 & Indeks Penilaian Kumulatif & $10 \%$ & 70 & 7.00 \\
\hline 2 & K002 & Tes Potensi Akademik & $15 \%$ & 85 & 12.75 \\
\hline 3 & K003 & Mikroteaching & $40 \%$ & 80 & 32.00 \\
\hline 4 & K004 & Wawancara & $20 \%$ & 80 & 16.00 \\
\hline 5 & K005 & Tes Psikotes & $15 \%$ & 75 & 11.25 \\
\hline \multicolumn{5}{c}{ Total Penilaian } \\
\hline
\end{tabular}

2. Penilaian terhadap alternatif A002 atas nama Nur Yanti Lumban Gaol, berikut pemaparan dari proses perhitungan dari Multi Factor Evaluation Process :

Tabel 5. Data Penilaian Alternatif Kedua

\begin{tabular}{cclccc}
\hline No & $\begin{array}{c}\text { Kode } \\
\text { Kriteria }\end{array}$ & \multicolumn{1}{c}{ Daftar Kriteria } & Nilai Bobot & $\begin{array}{c}\text { Nilai } \\
\text { Alternatif }\end{array}$ & $\begin{array}{c}\text { Hasil } \\
\text { Perhitungan }\end{array}$ \\
\hline 1 & K001 & Indeks Penilaian Kumulatif & $10 \%$ & 80 & 8.00 \\
\hline 2 & K002 & Tes Potensi Akademik & $15 \%$ & 75 & 11.25 \\
\hline 3 & K003 & Mikroteaching & $40 \%$ & 75 & 30.00 \\
\hline
\end{tabular}




\begin{tabular}{cccccc}
\hline No & $\begin{array}{c}\text { Kode } \\
\text { Kriteria }\end{array}$ & \multicolumn{1}{c}{ Daftar Kriteria } & Nilai Bobot & $\begin{array}{c}\text { Nilai } \\
\text { Alternatif }\end{array}$ & $\begin{array}{c}\text { Hasil } \\
\text { Perhitungan }\end{array}$ \\
\hline 4 & K004 & Wawancara & $20 \%$ & 85 & 17.00 \\
\hline 5 & K005 & Tes Psikotes & $15 \%$ & 80 & 12.00 \\
\hline \multicolumn{2}{c}{ Total Penilaian } \\
\hline
\end{tabular}

3. Penilaian terhadap alternatif A003 atas nama Khairi Ibnu Utama, berikut pemaparan dari proses perhitungan dari Multi Factor Evaluation Process :

Tabel 6. Data Penilaian Alternatif Ketiga

\begin{tabular}{cclccc}
\hline No & $\begin{array}{c}\text { Kode } \\
\text { Kriteria }\end{array}$ & \multicolumn{1}{c}{ Daftar Kriteria } & Nilai Bobot & $\begin{array}{c}\text { Nilai } \\
\text { Alternatif }\end{array}$ & $\begin{array}{c}\text { Hasil } \\
\text { Perhitungan }\end{array}$ \\
\hline 1 & K001 & Indeks Penilaian Kumulatif & $10 \%$ & 70 & 7.00 \\
\hline 2 & K002 & Tes Potensi Akademik & $15 \%$ & 85 & 12.75 \\
\hline 3 & K003 & Mikroteaching & $40 \%$ & 85 & 34.00 \\
\hline 4 & K004 & Wawancara & $20 \%$ & 75 & 15.00 \\
\hline 5 & K005 & Tes Psikotes & $15 \%$ & 80 & 12.00 \\
\hline \multicolumn{5}{c}{ Total Penilaian } \\
\hline
\end{tabular}

4. Penilaian terhadap alternatif A004 atas nama Gilang Ramadhan, berikut pemaparan dari proses perhitungan dari Multi Factor Evaluation Process :

Tabel 7. Data Penilaian Alternatif Keempat

\begin{tabular}{cclccc}
\hline No & $\begin{array}{c}\text { Kode } \\
\text { Kriteria }\end{array}$ & \multicolumn{1}{c}{ Daftar Kriteria } & Nilai Bobot & $\begin{array}{c}\text { Nilai } \\
\text { Alternatif }\end{array}$ & $\begin{array}{c}\text { Hasil } \\
\text { Perhitungan }\end{array}$ \\
\hline 1 & K001 & Indeks Penilaian Kumulatif & $10 \%$ & 80 & 8.00 \\
\hline 2 & K002 & Tes Potensi Akademik & $15 \%$ & 90 & 13.50 \\
\hline 3 & K003 & Mikroteaching & $40 \%$ & 70 & 28.00 \\
\hline 4 & K004 & Wawancara & $20 \%$ & 75 & 15.00 \\
\hline 5 & K005 & Tes Psikotes & $15 \%$ & 75 & 11.25 \\
\hline \multicolumn{7}{c}{ Total Penilaian } \\
\hline
\end{tabular}

5. Penilaian terhadap alternatif A005 atas nama Afdal Alhafiz, berikut pemaparan dari proses perhitungan dari Multi Factor Evaluation Process :

Tabel 8. Data Penilaian Alternatif Kelima

\begin{tabular}{cclccc}
\hline No & $\begin{array}{c}\text { Kode } \\
\text { Kriteria }\end{array}$ & \multicolumn{1}{c}{ Daftar Kriteria } & Nilai Bobot & $\begin{array}{c}\text { Nilai } \\
\text { Alternatif }\end{array}$ & $\begin{array}{c}\text { Hasil } \\
\text { Perhitungan }\end{array}$ \\
\hline 1 & K001 & Indeks Penilaian Kumulatif & $10 \%$ & 80 & 8 \\
\hline 2 & K002 & Tes Potensi Akademik & $15 \%$ & 75 & 11,25 \\
\hline 3 & K003 & Mikroteaching & $40 \%$ & 80 & 32 \\
\hline 4 & K004 & Wawancara & $20 \%$ & 80 & 16 \\
\hline 5 & K005 & Tes Psikotes & $15 \%$ & 85 & 12,75 \\
\hline \multicolumn{7}{c}{ Total Penilaian } \\
\hline
\end{tabular}

6. Penilaian terhadap alternatif A006 atas nama Amrullah, berikut pemaparan dari proses perhitungan dari Multi Factor Evaluation Process :

Tabel 9. Data Penilaian Alternatif Keenam

\begin{tabular}{cclccc}
\hline No & $\begin{array}{c}\text { Kode } \\
\text { Kriteria }\end{array}$ & \multicolumn{1}{c}{ Daftar Kriteria } & Nilai Bobot & $\begin{array}{c}\text { Nilai } \\
\text { Alternatif }\end{array}$ & $\begin{array}{c}\text { Hasil } \\
\text { Perhitungan }\end{array}$ \\
\hline 1 & K001 & Indeks Penilaian Kumulatif & $10 \%$ & 70 & 7.00 \\
\hline 2 & K002 & Tes Potensi Akademik & $15 \%$ & 80 & 12.00 \\
\hline 3 & K003 & Mikroteaching & $40 \%$ & 85 & 34.00 \\
\hline 4 & K004 & Wawancara & $20 \%$ & 80 & 16.00 \\
\hline 5 & K005 & Tes Psikotes & $15 \%$ & 75 & 11.25 \\
\hline \multicolumn{5}{c}{ Total Penilaian } \\
\hline
\end{tabular}


JURNAL MEDIA INFORMATIKA BUDIDARMA, Vol 3, No 3, Juli 2019

ISSN 2614-5278 (media cetak)

ISSN 2548-8368 (media online)

Hal 183-190 | DOI: 10.30865/mib.v3i3.1184

7. Penilaian terhadap alternatif A007 atas nama Wahyu Riansyah, berikut pemaparan dari proses perhitungan dari Multi Factor Evaluation Process :

Tabel 10. Data Penilaian Alternatif Ketujuh

\begin{tabular}{cclccc}
\hline No & $\begin{array}{c}\text { Kode } \\
\text { Kriteria }\end{array}$ & \multicolumn{1}{c}{ Daftar Kriteria } & Nilai Bobot & $\begin{array}{c}\text { Nilai } \\
\text { Alternatif }\end{array}$ & $\begin{array}{c}\text { Hasil } \\
\text { Perhitungan }\end{array}$ \\
\hline 1 & K001 & Indeks Penilaian Kumulatif & $10 \%$ & 90 & 9.00 \\
\hline 2 & K002 & Tes Potensi Akademik & $15 \%$ & 90 & 13.50 \\
\hline 3 & K003 & Mikroteaching & $40 \%$ & 75 & 30.00 \\
\hline 4 & K004 & Wawancara & $20 \%$ & 80 & 16.00 \\
\hline 5 & K005 & Tes Psikotes & $15 \%$ & 80 & 12.00 \\
\hline \multicolumn{5}{c}{ Total Penilaian }
\end{tabular}

8. Penilaian terhadap alternatif A008 atas nama Muhammad Rendy, berikut pemaparan dari proses perhitungan dari Multi Factor Evaluation Process :

Tabel 11. Data Penilaian Alternatif Kedelapan

\begin{tabular}{cclccc}
\hline No & $\begin{array}{c}\text { Kode } \\
\text { Kriteria }\end{array}$ & \multicolumn{1}{c}{ Daftar Kriteria } & Nilai Bobot & $\begin{array}{c}\text { Nilai } \\
\text { Alternatif }\end{array}$ & $\begin{array}{c}\text { Hasil } \\
\text { Perhitungan }\end{array}$ \\
\hline 1 & K001 & Indeks Penilaian Kumulatif & $10 \%$ & 80 & 8.00 \\
\hline 2 & K002 & Tes Potensi Akademik & $15 \%$ & 75 & 11.25 \\
\hline 3 & K003 & Mikroteaching & $40 \%$ & 90 & 36.00 \\
\hline 4 & K004 & Wawancara & $20 \%$ & 70 & 14.00 \\
\hline 5 & K005 & Tes Psikotes & $15 \%$ & 85 & 12.75 \\
\hline \multicolumn{5}{c}{ Total Penilaian }
\end{tabular}

9. Penilaian terhadap alternatif A009 atas nama Khuzaimah Panjaitan, berikut pemaparan dari proses perhitungan dari Multi Factor Evaluation Process :

Tabel 12. Data Penilaian Alternatif Kesembilan

\begin{tabular}{cclccc}
\hline No & $\begin{array}{c}\text { Kode } \\
\text { Kriteria }\end{array}$ & \multicolumn{1}{c}{ Daftar Kriteria } & Nilai Bobot & $\begin{array}{c}\text { Nilai } \\
\text { Alternatif }\end{array}$ & $\begin{array}{c}\text { Hasil } \\
\text { Perhitungan }\end{array}$ \\
\hline 1 & K001 & Indeks Penilaian Kumulatif & $10 \%$ & 80 & 8.00 \\
\hline 2 & K002 & Tes Potensi Akademik & $15 \%$ & 85 & 12.75 \\
\hline 3 & K003 & Mikroteaching & $40 \%$ & 85 & 34.00 \\
\hline 4 & K004 & Wawancara & $20 \%$ & 90 & 18.00 \\
\hline 5 & K005 & Tes Psikotes & $15 \%$ & 70 & 10.50 \\
\hline \multicolumn{7}{c}{ Total Penilaian } \\
\hline
\end{tabular}

10. Penilaian terhadap alternatif A010 atas nama Deski Rilana, berikut pemaparan dari proses perhitungan dari Multi Factor Evaluation Process :

Tabel 13. Data Penilaian Alternatif Kesepuluh

\begin{tabular}{cclccc}
\hline No & $\begin{array}{c}\text { Kode } \\
\text { Kriteria }\end{array}$ & \multicolumn{1}{c}{ Daftar Kriteria } & Nilai Bobot & $\begin{array}{c}\text { Nilai } \\
\text { Alternatif }\end{array}$ & $\begin{array}{c}\text { Hasil } \\
\text { Perhitungan }\end{array}$ \\
\hline 1 & K001 & Indeks Penilaian Kumulatif & $10 \%$ & 70 & 7.00 \\
\hline 2 & K002 & Tes Potensi Akademik & $15 \%$ & 80 & 12.00 \\
\hline 3 & K003 & Mikroteaching & $40 \%$ & 75 & 30.00 \\
\hline 4 & K004 & Wawancara & $20 \%$ & 80 & 16.00 \\
\hline 5 & K005 & Tes Psikotes & $15 \%$ & 80 & 12.00 \\
\hline \multicolumn{5}{c}{ Total Penilaian } \\
\hline
\end{tabular}

\subsection{Hasil Perangkingan}

Dari proses penilaian yang telah dilakukan dengan menggunakan Multi Factor Evaluation Process maka proses selanjutnya adalah melakukan perangkingan yang dimulai dari hasil penilaian yang tertinggi, hal ini dilakukan untuk mengetahui alternatif yang dapat diterima sebagai Asisten Dosen. Adapun hasil perangkingan dari proses perhitungan menggunakan Multi Factor Evaluation Process pada penerimaan Asisten Dosen adalah sebagai berikut : 
Tabel 14. Data Penilaian Alternatif Kesepuluh

\begin{tabular}{cclc}
\hline Rangking & $\begin{array}{c}\text { Kode } \\
\text { Alternatif }\end{array}$ & \multicolumn{1}{c}{ Daftar Calon Asisten Dosen } & Total Nilai \\
\hline 1 & A009 & Khuzaimah Panjaitan & 83.25 \\
\hline 2 & A008 & Muhammad Rendy & 82.00 \\
\hline 3 & A003 & Khairi Ibnu Utama & 80.75 \\
\hline 4 & A007 & Wahyu Riansyah & 80.50 \\
\hline 5 & A006 & Amrullah & 80.25 \\
\hline 6 & A005 & Afdal Alhafiz & 80.00 \\
\hline 7 & A001 & Masyuni Hutasuhut & 79.00 \\
\hline 8 & A002 & Nur Yanti Lumban Gaol & 78.25 \\
\hline 9 & A010 & Deski Rilana & 77.00 \\
\hline 10 & A004 & Gilang Ramadhan & 75.75 \\
\hline
\end{tabular}

Berdasarkan hasil perangkingan yang telah dilakukan maka selanjutnya akan dilakukan proses pemilihan Asisten Dosen sesuai dengan kebutuhan institusi, untuk saat ini institusi memerlukan lima alternatif yang memiliki nilai tertinggi maka dapat disimpulkan bahwa nama altrnatif yang berada pada rangking satu sampai dengan lima dinyatakan layak untuk dijadikan Asisten Dosen, namun proses perhitungan Multi Factor Evaluation Process nantinya akan diserahkan kepada pimpinan institusi untuk dijadikan sebagai bahan pendukung dalam pengambilan keputusan tentang penerimaan Asisten Dosen.

\section{IMPLEMENTASI}

Pengimplementasian Sistem Pendukung Keputusan ini dilakukan dengan menciptakan suatu layanan aplikasi yang mampu menghasilkan keputusan tentang penerimaan Asisten Dosen dengan menggunakan Multi Factor Evaluation Process. Pengujian sistem ini dimulai dari penentuan kriteria penilaian yang akan digunakan dalam proses penilaian kemudian selanjutnya adalah proses pemasukan data alternatif yaitu data diri calon Asisten Dosen dan proses terkahir adalah melakukan perhitungan dengan menerapkan Multi Factor Evaluation Process sehingga menghasilkan keputusan tentang penerimaan Asisten Dosen. Berikut ini adalah tahapan dari pengujian sistem yang dihasilkan :

\section{Pengolahan Data Kriteria}

Dalam melakukan penyeleksian terhadap calon Asisten Dosen, maka perlu terlebih dahulu memasukkan data kriteria penilaian yang akan digunakan untuk menghitung nilai alternatif yang ada. Dalam pengolahan data kriteria ini juga disajikan data nilai pembobotan dari masing-masing kriteria. Berikut ini interface dari halaman pengolahan data kriteria :

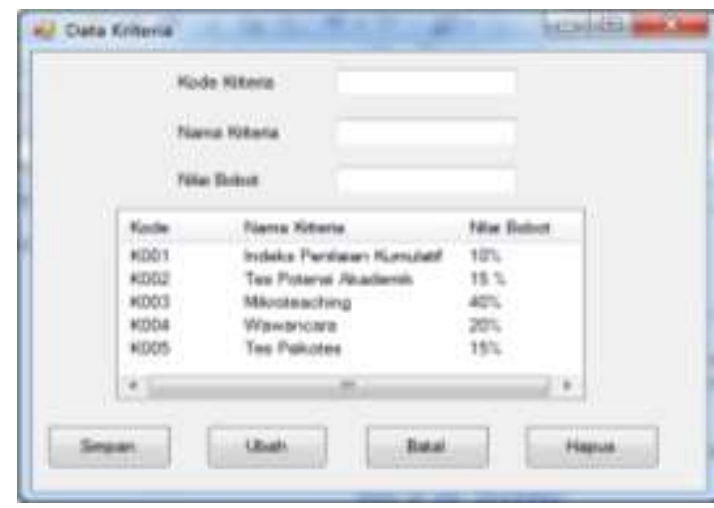

Gambar 2. Halaman Data Kriteria

Field yang tersedia dalam form data kriteria ini adalah kode kriteria, nama kriteria, dan nilai bobot, kemudian pada form data kriteria terdapat pengolahan data, seperti perintah simpan data kriteria, kemudian perintah ubah data kriteria, serta perintah hapus data diri kriteria, hal ini dilakukan untuk mengantisipasi perubahan data pada kriteria yang ditetapkan oleh institusi.

\section{Pengolahan Data Alternatif}

Pada proses selanjutnya dilakukan pemasukan data alternatif pada penyeleksian terhadap calon Asisten Dosen, yaitu memasukkan data alternatif atau calon Asisten Dosen sesuai dengan indentitas diri pada calon Asisten Dosen. Berikut ini interface dari halaman pengolahan data alternatif : 


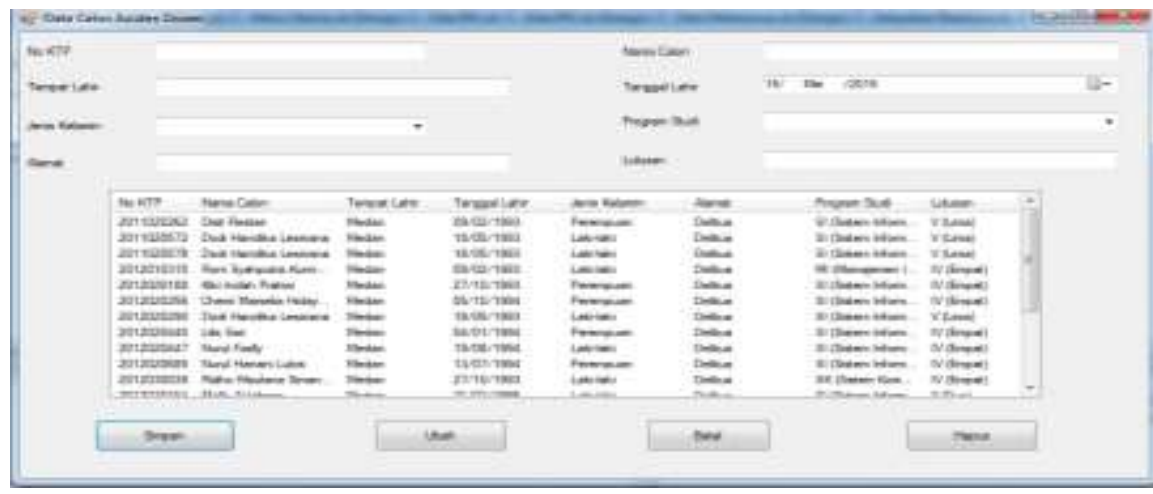

\section{Gambar 2. Halaman Data Alternatif}

Pada form data alternatif ini terdapat field yang berkaitan dengan identitas diri calon Asisten Dosen yang meliputi kode alternatif, nama, alamat, lulusan, tempat tanggal lahir, dan agama terdapat pengolahan data, seperti penyimpanan data, perubahan data, serta penghapusan data diri jika terdapat perubahan pada identitas diri alternatif hal ini dilakukan untuk mengantisipasi perubahan data pada calon Asisten Dosen dan dapat diterapkan pada suatu saat mendatang oleh institusi.

\section{Pengolahan Nilai Alternatif}

Penerapan metode Multi Factor Evaluation Process dilakukan pada form pengolahan nilai, yang berisi tentang seluruh nilai dari masing-masing alternatif dari setiap kriteria yang ada dan hasil perhitungan dari Multi Factor Evaluation Process. Berikut merupakan tampilan dari form pengolahan nilai :

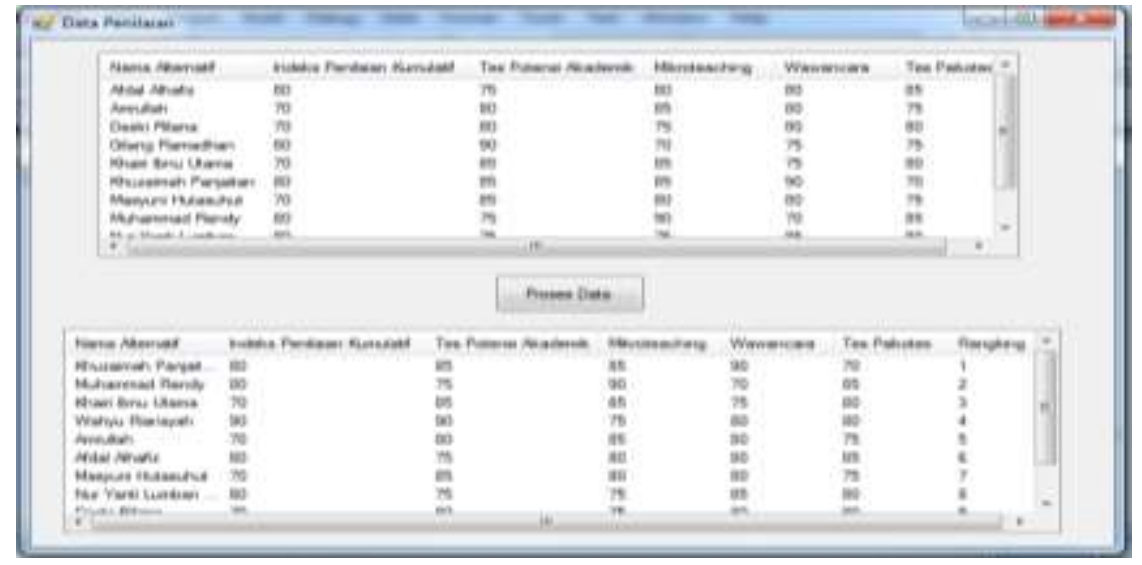

Gambar 3. Halaman Pengolahan Nilai

Layanan pengolahan nilai ini dimulai dari memasukkan seluruh nilai dari masing-masing alternatif kemudian memproses nilai tersebut sesuai dengan nilai bobot dari setiap kriteria dengan menggunakan metode Multi Factor Evaluation Process selanjutnya akan muncul hasil perangkingan dari proses perhitungan yang telah dilakukan.

\section{KESIMPULAN}

Berdasarkan hasil penelitian yang telah diperoleh tentang penerapan metode Multi Factor Evaluation Process dalam proses penyeleksian Asisten Dosen, maka dapat disimpulkan sebagai berikut :

1. Pembangunan Sistem Pendukung Keputusan dalam proses penyeleksian Asisten Dosen ini memiliki tahapan yang meliputi : pembentukan kriteria beserta nilai bobot, kemudian melakukan perhitungan dengan menggunakan metode Multi Factor Evaluation Process dan melakukan perangkinan nilai berdasarkan penilaian yang telah dilakukan serta pengimplementasian sistem dalam bentuk layanan aplikasi sehingga dapat digunakan oleh institusi.

2. Sistem Pendukung Keputusan dibangun dengan menerapkan Multi Factor Evaluation Process dalam proses penilaian berdasarkan kriteria serta nilai bobot masing-masing kriteria, sehingga sistem ini dapat menghasilkan nilai dari proses perhitungan yang dilakukan serta perangkingan untuk dapat dijadikan pengambilan kesimpulan dan mendukung keputusan dalam penerimaan Asisten Dosen 


\section{REFERENCES}

[1] J. P. Informatika et al., "METODE PROMETHEE," vol. 18, pp. 44-48, 2019.

[2] P. Radanliev, "Cyber risk from IoT technologies in the supply chain - discussion on supply chains decision support system for the digital economy," no. March, 2019.

[3] E. K. Zavadskas, J. Antucheviciene, and P. Chatterjee, Multiple-Criteria Decision Making ( MCDM ) Techniques for Business Processes Information Management, no. Mcdm. 2019.

[4] D. L. Kurniasih, "SISTEM PENDUKUNG KEPUTUSAN PEMILIHAN LAPTOP DENGAN METODE TOPSIS Diterbitkan Oleh : STMIK Budi Darma Medan Diterbitkan Oleh : STMIK Budi Darma Medan,” vol. III, no. April, pp. 6-13, 2019.

[5] S. H. Saragih, "PENERAPAN METODE ANALITYCAL HIERARCHY PROCESS ( AHP ) PADA SISTEM PENDUKUNG KEPUTUSAN PEMILIHAN LAPTOP,” pp. 82-88, 2019.

[6] S. Dedi, A. Pardede, M. Panjaitan, F. T. Waruwu, and P. S. Ramadhan, "HARAPAN KHUSUS LANSIA DENGAN MENERAPKAN VIKOR ( STUDI KASUS : DESA PATUMBAK II )," vol. 2, pp. 138-146, 2018

[7] S. Swastikawara, "BERKEBUTUHAN KHUSUS ( STUDI PADA KELOMPOK DEAF )," no. 2013, pp. 35-40, 2017.

[8] N. W. Al-hafiz, "SISTEM PENDUKUNG KEPUTUSAN PENENTUKAN KREDIT PEMILIKAN RUMAH MENERAPKAN MULTI-OBJECTIVE OPTIMIZATION ON THE BASIS OF RATIO ANALYSIS ( MOORA ),” vol. I, pp. 306-309, 2017.

[9] P. S. Ramadhan, "Sistem Pakar Pendeteksian Varicella Simplex Dengan Menggunakan Teorema Bayes," vol. 5, no. 5, pp. 454-459, 2018.

[10] D. N. Kirom, Y. Bilfaqih, and R. Effendie, "Sistem Informasi Manajemen Beasiswa ITS Berbasis Sistem Pendukung Keputusan Menggunakan Analytical Hierarchy Process," vol. 1, no. 1, 2019.

[11] P. S. Ramadhan, Mengenal Metode Sistem Pakar, 1st ed. Medan: Penerbit Uwais, 2018. 